\title{
HALAL INDUSTRY INFLUENCE ON STATE GDP - OIC COUNTRIES IN THE ASIAN REGION IN 2013 - 2016
}

\author{
Ahmad Samsul Badi ' \\ Islamic Economics, Faculty of Economics and Business, University of Airlangga
}

\begin{abstract}
The purpose of this study is to Determine the relationship between the influence of Islamic finance, halal food and halal tourism to GDP in the OIC countries in 2013-2016. This is a quantitative study using data panel method. The Data used is secondary Data from Thomson Reuters in 2013 - 2016. The results Showed that Islamic finance, halal food and sharia tourism cumulatively to positively Affect show. From the results of the independent F-test in know that
\end{abstract}

Keyword: Islamic finance, halal food, halal tourism, OIC, 


\section{Introduction}

\section{Introduction}

Islam is a religion rahmatan lil 'Alamin governing all aspects of human life. According to Irawan (2014) Islam is a religion that is perfect for being able to control all aspects of human life, not only spiritual but also muamalah aspects are very important and are executed directly in the life of society as a whole.

Islam is the religion of rahmatan lil 'alamin which regulates all aspects of human life. According to Irawan (2014) Islam is a religion that is perfectly in accordance with aspects of human life, not only spiritual aspects but also muamalah which is very important and is carried out directly in the life of society as a whole.following paragraph explains the obligation of a Muslim to run the lives of the lawful must use their letter of al-Baqarah verse 168;

$$
\text { بائها ألناس كلوا مما في آلأرض حلا طيبا ولا تتبعو ا خطوت ألثنيطن إنة لكم عدو مبين }
$$

Yaa ayyuhaa nnaasu kulu mimmaa Fll lardhi khalalan toyyiban wa la tattabi'u khutuwati syyatoon, innahu lakum 'aduwummubiin

"O mankind, eat of the lawful and good of what is in the earth, and do not follow the steps of Satan; because the devil indeed is a clear enemy."

Halal industry has now become a separate trend in the world community, not only among Muslims but from many other faiths. Halal industry is one of sector that supports the establishment of Islamic economics. The halal industry into the real sector of the economy in countries that are currently being developed or which have been advanced. Worldwide demand to against halal food not only from Muslims but also due to rising consumer prefernesi Non-Muslims to consume halal products. Racially diverse and different religious beliefs choose to buy products with the halal logo, giving a big boost to the halal industry. Some of the sectors which is currently in a good growth trend, namely the Islamic finance sector, the food is halal and syariah tourism.

With the rise in various sectors growing halal industry in the world, the Islamic finance, halal food and sharia tourism. It will be stimulating the growth of the economy, ie GDP. GDP is generated from the number of products in the form of goods or services produced within the borders of a country within a period of one year. 
With the growing Islamic financial sector, especially in Asia, to change the mindset of the people the importance of health. It also triggers the awareness of healthy food intake, thereby also resulting in peningkan growth in other sectors, namely the halal food sector.

According to Anwar (2004) unsafe food can lead to diseases caused by consuming foods that contain ingredients toxic compounds. Food safety, problems and threats in the development of food industry quality system is a shared responsibility, whereas Muslims have been obliged to apply toyyiban halalan system, namely by eating all kinds of foods are kosher. With the increase in the growth of halal food in the OIC countries, triggering the growth of other sectors. One of them is entertainment or recreation to tourism spot with Islamic principles or commonly called halal tourism.

Halal tourism or commonly called sharia tourism, has been widespread and popular in recent years, until tourism became an important sector, and in fact has been growing in recent years. According to (Timothy \& Olsen 2006) sharia tourism became one of the forms of research that is lacking in the research study in the tourism sector. But sharia tourism has increased and consistent in its market segment and has become the trend of the global tourism industry. The proof is that every year millions of people travel with the ultimate goal of pilgrimage to various countries in the world is estimated that almost 240 million people per year who come not only from Muslims, but also of the Christian and Hindu.

The purpose of this study was to determine the relationship between the influence of the Islamic finance, halal food, and sharia tourism to GDP in the country - the OIC countries in the year 2013 - 2016 partially and stimultan.

\section{Literature Review}

Consumer behavior is an action that directly involved in obtaining, and consuming the product or service, including in the decision making process to take it. (Setiadi, 2003). Meanwhile, according to Schiffman and Kanuk (2008: 6) says that studies consumer behavior is a study of how an individual makes the decision to allocate the available resources.

The theory of consumer behavior (consumer behavior) studied how humans choose among a wide selection of faces by utilizing the resources (resources) has. The theory of rational consumer behavior in the conventional economic paradigm 
based on the basic principles of utilitarianism. Initiated by Bentham who said that in general no one can know what is good for the sake of himself except the man himself. Thus restrictions on the freedom of the individual, either by other people or by the authorities, is a crime and there must be a compelling reason to do so.

According Munrokhim Misanam (2004), Muslim Consumer behavior is influenced by blessed. Due to the wisdom of blessing this has been promised by God as written in the Quran (Surah Maidah verse 88).

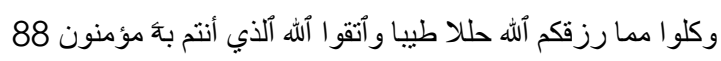

Wa kulu mimma razaqokumu allahu khlalan toyyiban, wattaquullaha alladzii antum bihi mukminiin

"And eat food lawful and good of what God has bestowed to you, and fear Allah that you have faith in Him."

The concept of blessing is a concept that is not negotiable in business behavior Muslim Thus, if manufacturers put the blessing it becomes one of the attributes of the products it sells, it will be a factor demand function slider to the right (positive).

According to Ibrahim Warde (2009) is a collection of Islamic financial instruments that not only covers banking institutions, but also non-bank institutions which include mutual funds, securities companies, insurance. According Deringer (2006) defines Islamic finance is a financial mechanism that is based on the laws and principles of Islam.

Halal food according to Hussein Bahresy (1981) is a good food that is permissible to eat according to the teachings of Islam, which according to the Qur'an and hadith al. While understanding that good food is any food can bring health to the body, can cause appetite and there is no prohibition in the Quran and hadith. But in other respects, the necessary information more clearly based on something ijma'dan Qiyas texts of a general nature to be explored by scholars that later did not cause syub law-had (casts doubt). And the scholars have ijma 'about halal livestock animals such as camels, cows and goats as well as Prohibition everything that could pose a hazard in the form of poisoning, disease or the side effects.

Tourism is a human activity that is conscious, who gets services rotated among the people in a State itself / abroad, covering the standing of people from other areas to temporarily seek satisfaction of diverse and different from what 
happened, where he obtained a permanent job (Yoeti 2008). While Ramaini opinion (1992) that, tourism is everything connect to travel, including business objects and attractions as well as related efforts in the field.

The history of the development of tourism in Islam started by Juhaya (2014) when introduced pilgrimage, which means literally is visiting. while the term halal Tourism was first introduced to the public in 2000 at the OIC meeting. Tourism sharia introduced to the public as an alternative to meet the demand in order for a travel that is based on a lifestyle that fits the needs of a Muslim ketuka traveled.

According to McEachern (2000: 146) Gross Domestic Product (GDP) is a measure of the market value of final goods and services produced by resources that are within a country during a certain period, usually one year. GDP can also be used for studying the economy over time or to compare the economy in a given period.

Definition of Gross Domestic Product (GDP) by Sukirno (2004: 17), which explains that the National Revenue describe the country's production levels achieved in a given year and change from year to year. Then GDP has an important role in describing the level of economic activity is achieved by a country changes from year to year growth. National product or national income is a term that applies on the value of goods and services produced within a country in a particular year.GDP may reflect the performance of the economy, so the higher the GDP of a country can be said to be the better the economic performance in the country.

Based on the hypothesis of exposure in this study are:

$\mathrm{HI}=$ the Islamic finance sector, halal food sector and the tourism sector sharia have a significant impact on GDP in the State - State OIC region in 2013-2016.

$\mathrm{H} 2=$ the Islamic finance sector is partially memili a significant impact on GDP in the State OIC region in 2013-2016.

\section{Methods}

Research conducted by the author using a quantitative approach, which is a quantitative approach that explains the relationship between variables through hypothesis testing.

\section{1 identification Variables}


The variables in this study refers to the analysis model used by researchers to answer the problem. The analysis model contains several analytical techniques to give effect to GDP

1. the dependent variable

a. Islamic Finance (XI)

b. Halal Food (X2)

c. Islamic Tourism (X3)

2. The independent variable

a. GDP

\section{Operational definition}

To provide a clearer description of the variables used in this study, the variables are defined:

1. Islamic finance

2. Halal Food

3. Islamic tourism

This type of data is the annual data. Taken according to the research period of $2013-2016$ and is expressed in units of the index, which is obtained from Thomson Routhers Report.

\section{Types and Sources of Data}

Data used in this research are secondary data from the panel. Secondary data in this study were obtained from published reports Report Thonsom Reuters and also the data issued by the data fred.stlovisfed.org. In this study, using data on 2013 to 2016.

\section{Population and Sample Research}

The population in this study using state asia enrolled in the members of the OIC with the observation period for the year 2013-2016. The samples using limited data availability considerations. Selected samples are Malaysia, UAE, Saudi Arabia, Indonesia, Brunei Darussalam, Bahrain, Oman, Qatar, Turkey, Kuwait, Jordan, and Pakistan.

\section{Mechanical Analysis}

Panel Data Regression Methods 
Basically the panel data has three methods used in processing the data panel. According to Gujarati (2012: 238-239), the first method is the approach of the pooled least square (PLS). Second, the approach to the fixed effect model (FEM). Third, the wide approach random effect model (REM) . Here is an explanation and a model of the three methods:

1. Pooled Least Square

2. Fixed Effect Model

3. Random Effect Model

\section{Estimation Model Selection Panel}

1. F Test Statistic (Chow test)

2. Hausman test

3. Test Langrange Multiplier

\section{testing Statistics}

T-statistics (Partial)

T-statistics test was conducted intuk see the significance of the effect individually (partial) of the independent variables on the dependent variable in the model. One way to test this is the t-statistic by using the concept of P-value by comparing the value of the P-value (probability value of each variable) with a significance level used

Simultaneous F Test

F-statistic test aims to determine whether the independent variables together were able to explain the dependent variable. The F-statistic can be done by comparing the value of $F_{\text {arithmetic }}$ and Ftabel.

The coefficient of determination (R2)

The coefficient of determination $\left(\mathrm{R}^{2}\right)$ Is a measure that indicates the amount of degrees of ability to explain the independent variable on the dependent variable of one of these functions. 


\section{Result and Discussion}

This study uses three independent variables, namely the Islamic finance, halal food, and travel sharia affect the dependent variable is GDP countries of the OIC. The use of these variables aims to analyze the impact of the Islamic finance, halal food and travel sharia to GDP in the OIC countries of Asia in the study period (year 2013-2016).

The model used in this study is the method of panel data regression. Methods used for the data the data in this study is the combination of data between two data, that is the time series data (period 2013-2016) and cross section (20 OIC member countries in Asia). The initial stage of data processing is panel data regression to the following equation:

$$
G D P_{I T}=\alpha+\beta \text { finance }_{i t}+\beta \text { food }_{i t}+\beta \text { travel }_{i t}+e_{i t}
$$

The process of doing the panel data regression channeled through three types of model approachesie between the PLS, FEM, or REM. Selection of the best model seen through the test Chow and Hausman Test.

Chow test is used to determine a good model between PLS and FEM. The result is the confidence of $5 \%$, the value of Fcount> F table, then the best model is the FEM. After that perform Hausman Test to determine the best model between FEM and REM. Hausman test results showed that the best model between FEM and REM is the use of REM.

Based on test test that has been done can be in the know that the estimate by using three models, the CEM, FEM and REM. 
Table. 4.5

Results Estimates

\begin{tabular}{|c|c|c|c|c|}
\hline \multirow{2}{*}{\multicolumn{2}{|c|}{ Dependent variable }} & \multicolumn{3}{|l|}{ Model } \\
\hline & & \multirow{2}{*}{$\begin{array}{l}\text { CEM } \\
-1,25 E+ \\
09\end{array}$} & \multirow{2}{*}{$\begin{array}{l}\text { FEM } \\
-1,71 E+ \\
09\end{array}$} & \multirow{2}{*}{$\begin{array}{l}\text { BRAKE } \\
-1,50 \mathrm{E}+ \\
09\end{array}$} \\
\hline \multirow[t]{3}{*}{ finance } & coefficient & & & \\
\hline & t-statistic & $\begin{array}{l}- \\
1.027488\end{array}$ & $\begin{array}{l}- \\
3.780965\end{array}$ & $\begin{array}{l}- \\
3.438215\end{array}$ \\
\hline & prob & .3074 & 0.0004 & 0.0010 \\
\hline \multirow[t]{3}{*}{ Food } & coefficient & $\begin{array}{l}3,48 \mathrm{E}+ \\
09\end{array}$ & $\begin{array}{l}1,21 \mathrm{E}+ \\
09\end{array}$ & $\begin{array}{l}1,27 \mathrm{E}+ \\
09\end{array}$ \\
\hline & t-statistic & 1.337086 & $\begin{array}{l}- \\
1.928977\end{array}$ & 2.172118 \\
\hline & prob & .1852 & .0439 & .0330 \\
\hline \multirow[t]{3}{*}{ travel } & coefficient & $\begin{array}{l}3,97 \mathrm{E}+ \\
09\end{array}$ & $\begin{array}{l}-8,61 \mathrm{E}+ \\
08\end{array}$ & $\begin{array}{l}-8,00 \mathrm{E}+ \\
08\end{array}$ \\
\hline & t-statistic & 1.978289 & $\begin{array}{l}- \\
1.928977\end{array}$ & $\begin{array}{l}- \\
1.799886\end{array}$ \\
\hline & prob & .0515 & .0587 & .0758 \\
\hline \multirow[t]{3}{*}{ C } & coefficient & $\begin{array}{l}9,83 \mathrm{E}+ \\
09\end{array}$ & $\begin{array}{l}2,79 \mathrm{E}+ \\
11\end{array}$ & $\begin{array}{l}2,67 \mathrm{E}+ \\
11\end{array}$ \\
\hline & t-statistic & 0.123060 & 11.09540 & 3.880259 \\
\hline & prob & .9024 & 0.0000 & 0.0002 \\
\hline \multicolumn{2}{|c|}{ Probanilitas F-statistic } & 0.018954 & 0.000000 & 0.001533 \\
\hline \multicolumn{2}{|c|}{ R-squared } & 0.122030 & 0.995109 & 0.181945 \\
\hline \multicolumn{2}{|c|}{ Adjusted R-squared } & 0.087373 & 0.993221 & 0.149653 \\
\hline
\end{tabular}

Source: results of treatment with Eviews 9

ANALYSIS MODEL AND TESTING HYPOTHESES

Selection of Panel Data Estimation Model

\section{Chow test}

\begin{tabular}{|l|l|l|l|}
\hline Effects Test & statistics & df & Prob. \\
\hline $\begin{array}{l}\text { Cross- } \\
\text { section F }\end{array}$ & 535.507341 & $(19.57)$ & 0.0000 \\
\hline
\end{tabular}




\begin{tabular}{|l|l|l|l|}
\hline Cross- & 415.215107 & 19 & 0.0000 \\
section & & & \\
Chi- & & & \\
square & & & \\
\hline
\end{tabular}

shows the probability value Cross-Section $F$ is equal to 0.0000 is smaller than the $5 \%$ significance level $(a=0.05)$. It can be concluded that $\mathrm{HO}$ rejected and $\mathrm{H} 1$ accepted, so that the best model using the Fixed Effects Model (FEM). Hausman test is then performed to select the best estimation model between Fixed Effects Model (FEM) and Random Effects Model (REM).

Hausman test

\begin{tabular}{|l|l|l|l|}
\hline $\begin{array}{l}\text { test } \\
\text { Summary }\end{array}$ & $\begin{array}{l}\text { Chi-sq. } \\
\text { statistics }\end{array}$ & $\begin{array}{l}\text { Chi- } \\
\text { sq.df }\end{array}$ & $\begin{array}{l}\text { Pro } \\
\text { b. }\end{array}$ \\
\hline $\begin{array}{l}\text { Cross- } \\
\text { section } \\
\text { random }\end{array}$ & 5.488073 & 3 & 0.01 \\
42
\end{tabular}

Source: Processed Data Eviews

Based on the test table above shows the probability value Cross Section Random amounted to 0.1394 more than 5\% significance level ( $a=0.05$ ). can conclude that accept $\mathrm{HO}$ and $\mathrm{HI}$ rejected, so that the best model using the Random Effects Model (REM).

Test Statistics Collaborative

Partial test (T-test)

table

T Test Results

\begin{tabular}{|c|c|c|c|}
\hline & variable & t-Statistic & prob \\
\hline & finance & -3.438215 & 0.0010 \\
\hline & Food & -1.799886 & 0.0330 \\
\hline & travel & 3.880259 & 0.0758 \\
\hline
\end{tabular}

Based on the above table is known t test results as follows: 
1. Financial kosher has probability value of 0.0010 , meaning that the value of the variable probability of kosher food is below $5 \%$ significant number (> 0.05). Islamic financial negative effect on GDP in the OIC countries in Asia in 2013-2016 with a coefficient $-1,50 E+09$, so that if the Islamic finance increased by one unit will reduce GDP by $1,50 \mathrm{E}+09$.

2. Halal food has a probability value of 0.0330 , meaning that the probability value is below the $5 \%$ significance level $(>0.05)$. Halal food is a positive influence on GDP in the OIC countries in Asia in 2013-2016 with a coefficient $1,27 E+09$, so that if the kosher food increased by one unit will increase GDP by $1,27 \mathrm{E}+09$.

3. Travel sharia has probability value of 0.0758 , meaning the value of the travel variable Sharia is above the significant value of $5 \%$ or $0: 05$, so the sharia tourism variables do not have a relationship in a short time frame.

Simultaneous Test (F-test)

Table

F Test Results

\begin{tabular}{|l|l|}
\hline & Model \\
\hline Prob> F & 0.001533 \\
\hline
\end{tabular}

Based on the table it can be seen that the $F$ test results using the REM shows the $\mathrm{p}$-value $\mathrm{F}$ for 0.001533 , This means, $\mathrm{p}$-value $\mathrm{F}$ on models smaller than the 0.05 significance level so that it can be concluded that the $\mathrm{HO}$ is rejected and simultaneously all independent variables in models significantly influential to the GDP of the country - OIC parts of Asia.

coefficient of Determination 
The coefficient of determination (R2) is a measure that indicates how much the ability of independent variables in explaining the dependent variable in the model. The regression results in Table 4.1 FEM method produces R2 value of 0.181945 . The regression results indicate, the independent variable on the dependent variable model that explains the public welfare by 18.19 percent, while the remaining 81.19 percent is explained by other variables outside the model.

Hypothesis testing

Based on the analysis using panel data regression methods above, proving the hypothesis summarized as follows:

I. The first hypothesis states that sharia finance variables, halal food, and tourism partial sharia react to GDP in the OIC countries of Asia for the year 2013-2016. The hypothesis can not be accepted, because it is based on $\dagger$ test is known that the Islamic financial variables negatively affect GDP. Variable halal positive effect on GDP. Variable sharia tourism has no influence on GDP.

II. The second hypothesis states that the Islamic financial variables, halal food, and tourism together sharia effect on GDP of the OIC countries in Asia for the year 2013-2016. This hypothesis can be accepted, because it is based on test $\mathrm{F}$ known that the Islamic financial variables, kosher food, and tourism sharia significant effect on GDP in the OIC countries of Asia for the year 2013-2016.

\section{Discussion}

Islamic financial influence of the GDP in 2013 - 2016

Based on the results of the t test for the financial sector variables have a significant impact on GDP in the OIC countries in 2013 - 2016. This is evidenced by the following figures the probability of significance of $5 \%(0: 05)$. 
Hypothesis of this study is a significant influence between Islamic financial sector to GDP. Results from this study showed that the positive effect, so that it can be concluded that the hypothesis is accepted and vairabel researcher Islamic financial sector can be explained both pengauh premises Islamic financial sector to GDP in Asian OIC countries in 2013-2016.

According Almansyah (2012) Islamic financial development will bring kesahteraan equitable society and economic improvement. The Islamic finance closer to the real sector due to the product being offered, particularly the underlying traksaksi sharia financing in the real sector, so the impact is more obvious and boost economic growth. There is no product that is speculative, so as to have a strong resistance from the threat of crisis. Sharecropping system being the primary aspect of Islamic banking would bring benefits more equitable for all parties.

According Gudarzai (2013) in the Islamic finance long-term and significant impact positive because efective carry out its primary role as a reliable financial system and contributed significantly to the economy, especially economic development for economic prosperity.

Effect of kosher food to the GDP in 2013 - 2016

Based on the survey results revealed variable results halal positive significant effect on GDP - the OIC countries. According to the results of the t test, the variable value of halal food 0.0330 above its significance, meaning $\mathrm{HO}$ and $\mathrm{H} 1$ rejected.

Hypothesis of this study do not affect significantly advance of halal food sector to GDP. It can be concluded that the hypothesis is accepted and vairabel researchers halal food sector is less able to explain well the influence of the halal food sector to GDP in Asian OIC countries in 2013-2016.

This result is caused because the consumer tendency to not inspect or search for information about the halal certification to be purchased. Consumers will consume halal products because it is influenced by subjective norms and behavioral control. According Marselius (2002) subjective norm is the perceived social pressure to perform or not perform an treatment. There demand for kosher foods of society, from the family, the government, to the demands of religious 
leaders formed a consumer to follow the norms that exist in the vicinity, Negative votes will be accepted if the person does not eat meat or kosher food mainly obtained from family or those closest.

The influence of sharia tourism to GDP in 2013 - 2016

Based on the results of the t test for the travel sector variables sharia does not have a significant impact on GDP in the OIC countries in 2013 - 2016. This is evidenced by the above figures the probability of significance of $5 \%(0.05)$.

Hypothesis of this study is the significant influence of sharia anatar travel sector to GDP. Results from this study showed that the lack of effect on GDP in the OIC countries of Asia, is due to the number of years of research which is still too short.

In Nuryenti study (2016) about the factors that influence a tourist visit, noted that the increase in sharia tourism influenced by the service increased palayanan. This service is a facility - the existing facilities, such as toilets were clean and differentiated between male toilets - men and women, places of worship were comfortable. There is a restaurant that should follow the standards of kosher food service.

The influence of Islamic finance, halal food, Islamic Tourism to GDP OKI years 2013 $-2016$

Based on the test results for the variable $f$ the Islamic finance, halal food, and sharia tourism has a significant impact on GDP in the OIC countries in 2013 - 2016. This is evidenced by the following figures the probability of significance of $5 \%$ (0:05).

Hypothesis of this study is the significant influence of Islamic financial anatara, food kosher, sharia tourism to GDP. Results from this study showed that the positive 
effect, so that it can be concluded that the hypothesis is accepted and vairabel researcher Islamic financial sector can be explained both pengauh premises Islamic financial sector to GDP in Asian OIC countries in 2013-2016.

The results are consistent with research conducted by Hassan (2014) which concluded that halal industry push the economic growth. There positive results show the growing of halal industry will affect the increase in the value of GDP. Halal illegitimate Muslim life will greatly affect the worship and daily habits that do, the libertine long time will give a big impact to the growth perkonomian. Economic growth according to Islam is the continuous growth of production factors and provide kontribusai to human welfare.

\section{Conclusion}

The conclusions from the results of the effect of the relationship between the Islamic finance, halal food, and sharia tourism to GDP in the country - the OIC countries in the year 2013 - 2016 are:

1. Islamic financial sector, halal food, and sharia tourism, simultaneously a significant effect on GDP in the country - OIC region in 2013-2016.

2. Islamic financial sector, tourism and simultaneous partial sharia are significant effect on GDP in the country - OIC region in 2014 - 2015. The partial variable kosher food does not affect the GDP of the country - OIC region in 2013 2016.

Based on research that has been done, the advice that can be given as follows:

1. Independent variables used in this study was limited to the Islamic finance, halal food, and tourism sharia. In a subsequent study is expected to include variables - other lawful variables that influence economic growth / GDP, to be optimized again.

2. Next research are expected to expand the research theme, extend the research to learn more about better results. 


\section{References}

[1] Almansyah, Halim. 2012. Development and Prospect of Indonesian Islamic Banking: Challenges in 2015. MEA Welcoming Deputy Governor of Bank Indonesia

[2] Anwar, F. (2004) Food Safety. Editor: Baliwati, YF, A. Khomsan, CM Dwiriani. Introduction to Food and Nutrition. Governmental spreader: Jakarta.

[3] Damodar N. Gujarati and Dawn C. Porter. 2012. Fundamentals econometrika. Jakarta: Four Salemba.

[4] Gudarzi, FY and Dastan M. 2013. Analysis of Islamic Bank's Financing and Economic Growth: Panel Cointegration Approach. International Journal of Islamic and Middle Eastern Finance and Management. 156-172

[5] Hassan, Mujar. 2014. The Economics of Halal Industry. 1-15

[6] Hussein Bahresy, Guidelines for Islamic jurisprudence, Surabaya, Al-Ikhlas, 1981 , p. 303.

[7] Irawan, Deni. 2014 ISLAM AND PEACE buliding. Religion. Vol 10. 158-171.

[8] Juhaya s. Praja, Prawisata concept of Sharia. Paper presented at the National Seminar of tourism Syariah, Faculty of Sharia and Law UIN Bandung, Bandung, 2014.

[9] Maryanti, BC, No year PERPSEKTIF CONSUMER BEHAVIOR IN ISLAMIC ECONOMICS.

[10] Mukhtar, A. And Butt, MM (2012), "Intention to choose Halal products: the role of religiosity", Journal of Islamic Marketing, Vol. 3 No. 2, pp. 108-120.

[11] Munrokhim Misanam, "Theory of Consumer Choice In Islamic Perspective", paper presented at the National Symposium on Islamic Economic System II, organized by PPBEI-FEUB, Malang 28-29 May 2004

[12] Oka. A. Yoeti. 2008 stats and Tourism Development, the second printing. PT. Pradnya Paramita.

[13] Orda, j. ABEAMUC-j. 2002. Tourism as a long-run economic growth factors: the Spanish case. Applied economics, 34, 877-884.

[14] Syahriza, r. 2014. Based Tourism Sharia. HUMAN Falah, 1, 135-145.

[15] Thomson Reuters. 2013. The State of the Global Islamic Economy 2013 Report. Dubai: Thomson Reuters.

[16] Reuters. 2014 State of the Global Islamic Economy 2014 Report. Dubai: Thomson Reuters 
[17] Reuters. 2015 State of the Global Islamic Economy 2014 Report. Dubai: Thomson Reuters

[18] Reuters. 2016 State of the Global Islamic Economy 2016 Report. Dubai: Thomson Reuters

[19] Timothy, DJ, \& Olsen, H. (2006). Tourism, religion and spiritual journeys. Oxford: Routledge. 